\title{
Unusual and early onset IPEX syndrome: a case report
}

\author{
Dilek Doğruel ${ }^{1}$, Fatih Gürbüz ${ }^{2}$, İhsan Turan², Derya Ufuk Altıntaş ${ }^{1}$, Mustafa Yılmaz ${ }^{1}$, \\ Bilgin Yüksel ${ }^{2}$ \\ Departments of ${ }^{1}$ Pediatric Allergy and Immunology and ${ }^{2}$ Pediatric Endocrinology Çukurova University Faculty of Medicine, \\ Adana, Turkey. E-mail: dilekkaragoz1977@hotmail.com \\ Received: 22nd May 2018, Revised: 19th June 2018, 5th July 2018, 16th July 2018, Accepted: 20 th July 2018
}

SUMMARY: Doğruel D, Gürbüz F, Turan İ, Altıntaş DU, Yılmaz M, Yüksel B. Unusual and early onset IPEX syndrome: a case report. Turk J Pediatr 2019; 61: 580-584.

Immune dysregulation, polyendocrinopathy, enteropathy, X-linked (IPEX) syndrome is a rare disorder that causes systemic autoimmunity resulting from a mutation of the forkhead box protein 3 gene (FOXP3). A 2-year-old boy, was referred to the hospital due to vomiting and fever when he was 21 days old. On physical examination the patient was severely dehydrated, and his laboratory test results showed hyperglycemia and metabolic acidosis. Upon the continuance of the hyperglycemia which caused the patient to receive permanent insulin treatment, the patient was diagnosed with neonatal diabetes mellitus. Here, we report a 2-year-old boy with early-onset IPEX syndrome due to a c.1040G > A (p.R347H) mutation in exon 11 of the FOXP3 gene. Although the patient had missense mutation in his FOXP3 gene, he did not have other immunodysregulation symptoms. IPEX syndrome should be kept in mind in all the cases of associated neonatal diabetes mellitus in male neonates or infants.

Key words: FOXP3 mutation, IPEX syndrome, neonatal diabetes mellitus.

Neonatal diabetes mellitus (NDM), is a rare cause of hyperglycemia in the first month of life and its frequency is one in 90000-160000 live births. It can be permanent (PNDM) or transient (TNDM) and PNMD is often associated with genetic defects. ${ }^{1}$ Neonatal diabetes mellitus is genetically a heterogeneous disease and more than 20 responsible genes have been detected up until now. Mutations in the KCNJ11, ABCC 8 and INS genes are the most common cause of PNDM. ${ }^{2}$ FOXP3 is also a gene related to neonatal diabetes, and codes a forkhead box transcription factor (FOXP3) which is necessary for the function of the $\mathrm{CD} 4{ }^{+} \mathrm{CD} 25^{+}$Treg cells. ${ }^{3,4}$ The pathogenic variants in FOXP3 are typically related to immunodysregulation polyendocrinopathy enteropathy X-linked syndrome (IPEX). ${ }^{5}$ If a bone marrow transplant is not performed, IPEX syndrome is characterized with infections which threaten life in the first 2 years, NDM, enteropathy and eczema. Other autoimmune diseases which are seen in the clinic of the illness are coombs positive hemolytic anemia, thrombocytopenia, neutropenia, tubular nephropathy, ulcerative colit, alopecia, and autoimmune thyroid diseases. Uncommonly, FOXP3 mutations have been defined in cases without all the manifestations of IPEX syndrome, patients with neonatal diabetes without life-threatening enteropathy. ${ }^{6}$

The aim of our paper is to present a patient with IPEX syndrome and to highlight the atypical clinical characteristics and outcome of this disease.

\section{Case Report}

A 39-week normal for gestational age (birth weight $3.3 \mathrm{~kg}$ ) white male infant was referred for evaluation at three weeks of age with a history of vomiting and fever. At the physical examination, his skin was pale, skin turgor had reduced and the anterior fontanel was sunkken, S1-S2 were normal and a 2/6 degrees 
systolic murmur was heard at left midsternal border. His neonatal reflexes were hypoactive. His other system examinations were normal.

In his laboratory tests, the blood sugar level of the case was $1148 \mathrm{mg} / \mathrm{dL}$ and his serum and urine ketone was positive. Serum insulin level was $15.8 \mathrm{IU} / \mathrm{ml}$ (normal: 3-20), C peptid level $0.57 \mathrm{ng} / \mathrm{ml}$ (normal: 1.1-4.4), anti-insulin, islet-cell and glutamic acid decarboxylase antibodies were detected negative. The thyroid hormones were: thyroid stimulating hormone (TSH) $3.14 \mu \mathrm{IU} / \mathrm{mL}$ (normal: $0.5-9$ ), total T4 $8.2 \mu \mathrm{m} / \mathrm{dL}$ (normal: 6.6-17.2), free T4 $1.2 \mathrm{ng} /$ $\mathrm{dL}$ (normal: 0.9- 2.3). The anti-microsomal and anti-thyroglobulin antibodies were determined negative. In complete blood count analysis leukocyte, neutrophil, lymphocyte, eosinophil, and platelet levels were normal for his age. Lymphocyte immunophenotyping showed normal total $\mathrm{T}$ lymphocytes, B lymphocyte and natural killer cell counts, immunoglobulin levels were also within normal range. (Table I) ${ }^{7-9}$
The dehydration of the patient who had hyperglycemia and metabolic acidosis was relieved, and intravenous insulin infusion was started. After the dehydration and hyperglycemia were cleared the insulin infusion was stopped. However, the patient's hyperglycemia developed again. The patient was hospitalized for two months and glucose regulation was provided. The NDM diagnosed patient was discharged from the hospital with 2 units of subcutaneous NPH insulin per day.

After the diagnosis of NDM, DNA samples of the child and the parents were sent to the University of Çukurova, Medical School, Department of Genetics. The DNA analysis found mutation at exon 10 of FOXP3 gene c.1040G > A, p.R347H, which confirmed IPEX syndrome (Fig. 1). The same mutation in heterozygotic state was found in the mother. The patient is now 2 years old and his growth and development have been good and he has not had any other immune dysregulation and

Table I. Blood Count, Lymphocyte Subsets and Immunoglobulins levels.

\begin{tabular}{lcc}
\hline Blood index & Laboratory results & Reference range $^{7-9}$ \\
\hline White blood cell $\left[\mathrm{x} 10^{9} / \mathrm{L}\right]$ & 6.1 & {$[6-17]$} \\
Platelet $\left[\mathrm{x} 10^{9} / \mathrm{L}\right]$ & 332 & {$[150-400]$} \\
Neutrophil $\left[\mathrm{x} 10^{9} / \mathrm{L}\right]$ & 2.51 & {$[1-8]$} \\
Lymphocyte $\left[\mathrm{x} 10^{/} / \mathrm{L}\right]$ & 3.6 & {$[3-9]$} \\
Eosinophils $\left[\mathrm{x} 10^{9} / \mathrm{L}\right]$ & 0.25 & {$[<0.3]$} \\
$\mathrm{CD} 3+\mathrm{CD} 16-56-[\%]$ & 51.8 & {$[51-77]$} \\
{$\left[\mathrm{x} 10^{9} / \mathrm{L}\right]$} & 3.1 & {$[1.3-6.5]$} \\
$\mathrm{CD} 3+\mathrm{CD} 4+[\%]$ & 37.6 & {$[29-55]$} \\
{$\left[\mathrm{x} 10^{9} / \mathrm{L}\right]$} & 2.25 & {$[0.7-4.5]$} \\
$\mathrm{CD} 3+\mathrm{CD} 8+[\%]$ & 14 & {$[15-33]$} \\
{$\left[\mathrm{x} 10^{9} / \mathrm{L}\right]$} & 0.78 & {$[0.4-3.2]$} \\
$\mathrm{CD} 3-\mathrm{CD} 16-56+[\%]$ & 5.8 & {$[4-15]$} \\
{$\left[\mathrm{x} 10^{9} / \mathrm{L}\right]$} & 0.34 & {$[0.2-1.3]$} \\
$\mathrm{CD} 19+[\%]$ & 40.4 & {$[17-41]$} \\
{$\left[\mathrm{x} 10^{9} / \mathrm{L}\right]$} & 2.4 & {$[0.5-3.6]$} \\
$\mathrm{HLA} \mathrm{DR}+[\%]$ & 43.1 & {$[19-43]$} \\
{$\left[\mathrm{x} 10^{9} / \mathrm{L}\right]$} & 2.6 & {$[0.6-3.8]$} \\
$\mathrm{IgG}[\mathrm{mg} / \mathrm{dl}]$ & 537 & {$[507-1407]$} \\
$\mathrm{IgM}[\mathrm{mg} / \mathrm{dl}]$ & 72 & {$[63-298]$} \\
$\mathrm{IgA}[\mathrm{mg} / \mathrm{dl}]$ & 28 & {$[18-171]$} \\
$\mathrm{IgE}[\mathrm{IU} / \mathrm{L}]$ & 37 & {$[<90]$} \\
\hline & &
\end{tabular}




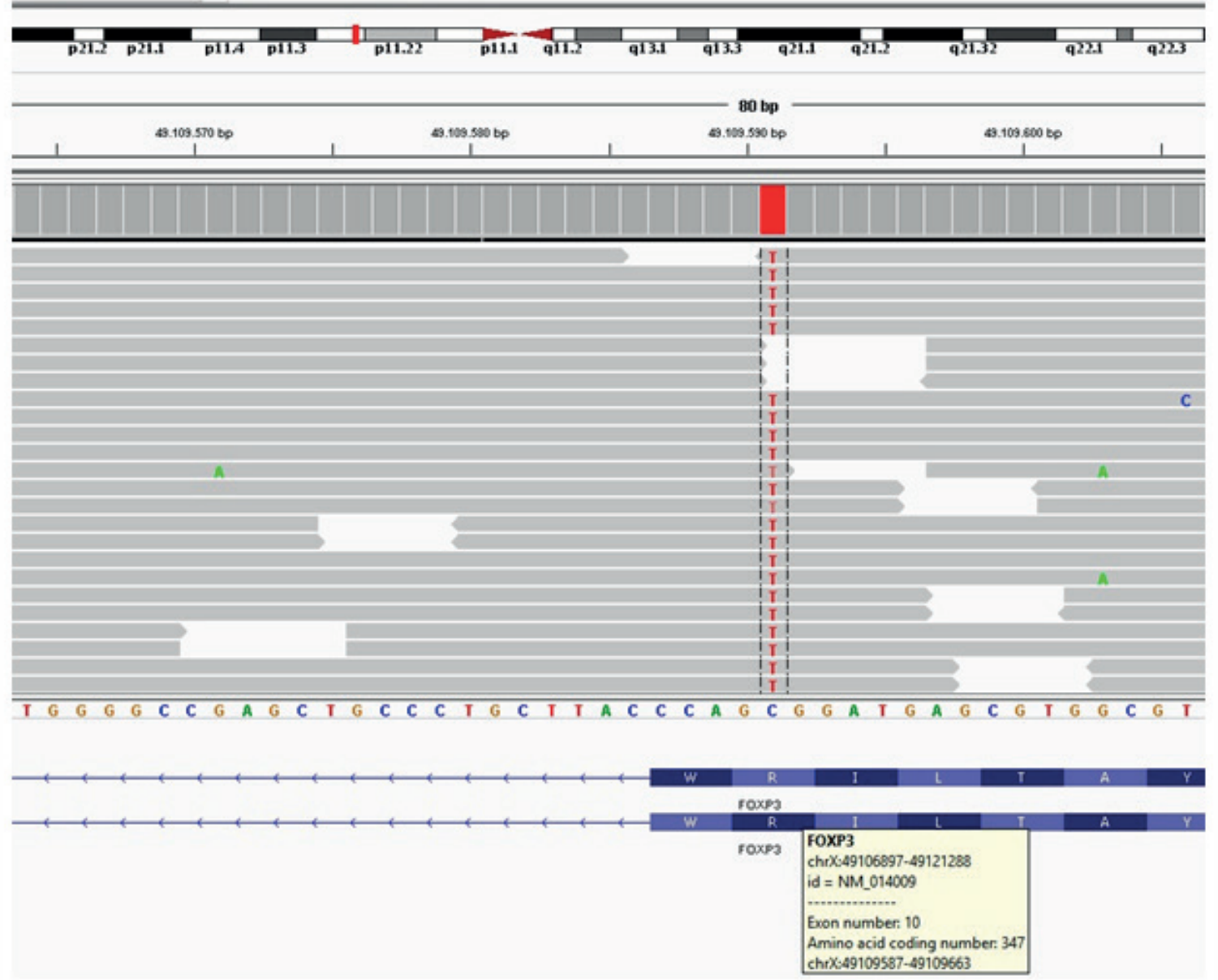

Fig. 1. Hemisigote mutation in FOXP3 gene in integrative genomic image with next generation sequence system (MiSeq, Illumina).

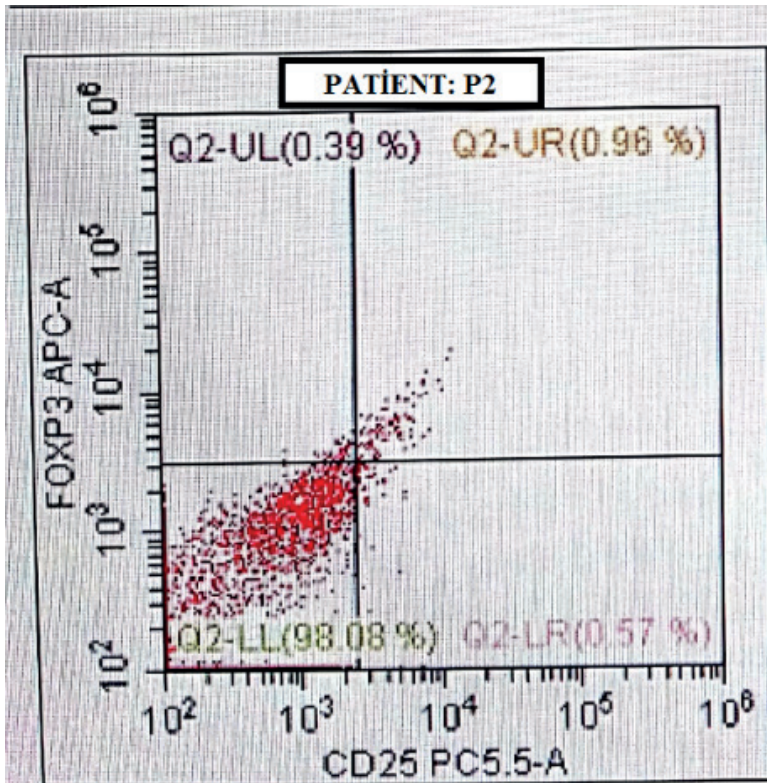

Fig. 2a. Expression of FOXP3 in CD25 + T cells of patient

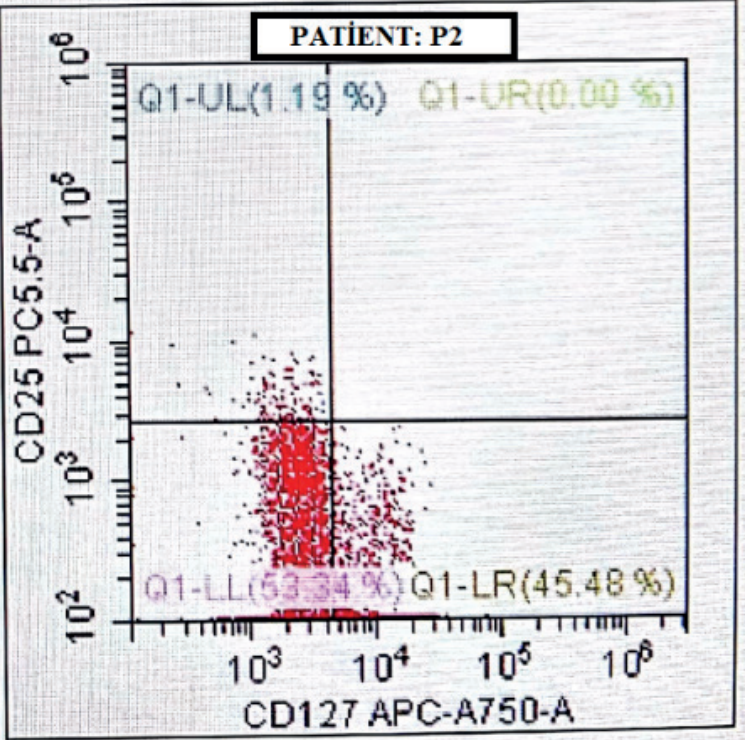

Fig. 2b. Expression of FOXP3 in CD25 + T cells of control subjects 
immune deficiency symptoms so far.

Informed consent was obtained from the patient's parents for publication.

\section{Discussion}

IPEX is a rare disease with a variable clinical phenotype, likely associated with the specific mutation and degree of functional FOXP3 protein expression. ${ }^{10}$ In 1982, for the first time Powell et al. ${ }^{11}$ reported a X-linked syndrome with diarrhea, polyendocrinopathy, and fatal infections in infancy. Later, the locus for IPEX to a 17 cM interval defined by markers DXS8083 and DXS8107 at Xp11.23-q13.3 was mapped by Bennet et al. ${ }^{12}$ FOXP3, is the necessary transcription factor for the regulatory function of Treg cells which suppress many functions of effector $\mathrm{T}$ (Teff) cells. At least 70 different FOXP3 gene mutations have been reported. As new cases proven by genetic analysis were added over the world, considerable clinical heterogeneity was reported. ${ }^{13-15}$ On the other hand, similar genotypes did not always give rise to similar phenotypes in terms of disease manifestation and severity of IPEX. ${ }^{16}$

Patients who have mutations which delete the expression of the functional FOXP3 protein (such as patients who have mutations at the polyadenylation area like frameshift or premature stop kodone) have the tendency to have a serious clinical chart. Nonetheless, the difference in the histopathologic lesions found in the target organs between patients who carry the same mutation, is evidence that the genotype is not fully linked to clinical characteristics. ${ }^{17}$ Although, our patient had missense mutation in his FOXP3 gene, besides NDM he did not have other immunodysregulation symptoms or severe infection history and he had shown normal growth and development. In general, the absence of genotype fenotype correlation suggests the role of epigenetic regulation in FOXP3's complex intracellular interactions and emergence of clinical symptoms. ${ }^{18}$ Additionally, these atypical clinical manifestations of IPEX point out existing possible underestimation of the frequency of disease.
Although FOXP3 mutations are characterized by decreased or absent protein expression, mutations with normal protein expression have been identified. It has been reported that a milder phenotype is observed in these cases where protein expression is normal. However, it is unclear in these cases whether diabetes and other features are caused by a decrease in protein expression or a subset of dysfunctional regulatory CD4 $\mathrm{T}$ cells exerting a protein with an abnormal function. ${ }^{16}$ In our patient, FOXP3 protein expression was normal (Fig. 2), but FOXP3 Sanger sequencing confirmed the clinical suspicion of IPEX by detecting a missense variant.

Genetic studies should be performed in these cases since demonstration of molecular impairment leading to NDM is important in determining the prognosis and treatment plan of the disease. Genetic analysis is also important in NDM, not only for definitive diagnosis but also for giving necessary genetic counseling to patient and family. Because hematopoietic stem cell transplantation led to resolve the defect in FOXP3 gene, not only the immunological problems but also autoimmune disorders may resolve.

\section{Acknowledgments}

We acknowledge the guidance of Asist Prof Atıl Bişgin (Chief of Department of Medical Genetic, Çukurova University Medical School, Adana) due to genetic consultation. No financial assistance was received to conduct the study.

\section{REFERENCES}

1. Wirth M, Jellimann JM, Jellimann S, Hascoet JM. Neonatal diabetes mellitus: Improved screening and early management of an underestimated disease. Clin Case Rep 2018; 6: 18-22.

2. Støy J, Edghill EL, Flanagan SE, et al; Neonatal Diabetes International Collaborative Group. Insulin gene mutations as a cause of permanent neonatal diabetes. Proc Natl Acad Sci U S A 2007; 104: 1504015044.

3. Greeley SA, Naylor RN, Philipson LH, Bell GI. Neonatal diabetes: An expanding list of genes allows for improved diagnosis and treatment. Curr Diab Rep 2011; 11: 519-532. 
4. d'Hennezel E, Bin Dhuban K, Torgerson T, Piccirillo $\mathrm{CA}$. The immunogenetics of immune dysregulation, polyendocrinopathy, enteropathy, $\mathrm{X}$ linked (IPEX) syndrome. J Med Genet 2012; 49: 291-302.

5. Wildin RS, Smyk-Pearson S, Filipovich AH. Clinical and molecular features of the immunodysregulation, polyendocrinopathy, enteropathy, X linked (IPEX) syndrome. J Med Genet 2002; 39: 537-545.

6. Rubio-Cabezas O, Minton JAL, Caswell R, et al. Clinical heterogeneity in patients with FOXP3 mutations presenting with permanent neonatal diabetes. Diabetes Care 2009; 32: 111-116.

7. Kaya Z. Tam kan sayım çıktılarının yorumlanması. Dicle Tip Dergisi 2013; 40: 521-528.

8. İkincioğulları A, Kendirli T, Doğu F, et al. Peripheral blood lymphocyte subsets in healthy Turkish children. Turk J Pediatr 2004; 46: 125-130.

9. Ladomenou F, Gaspar B. How to use immunoglobulin levels in investigating immune deficiencies. Arch Dis Child Educ Pract Ed 2016; 101: 129-135.

10. Smith E, Greeley SA, Ye H, et al. Extremely early onset IPEX syndrome caused by a novel small exonic deletion in FOXP3. J Pediatr Gastroenterol Nutr 2016; 63: e119-e120.

11. Powell BR, Buist NR, Stenzel P. An X-linked syndrome of diarrhea, polyendocrinopathy, and fatal infection in infancy. J Pediatr 1982; 100: 731-737.

12. Bennett CL, Brunkow ME, Ramsdell F, et al. A rare polyadenylation signal mutation of the FOXP3 gene (AAUAAA $\rightarrow$ AAUGAA) leads to the IPEX syndrome. Immunogenetics 2001; 53: 435-439.
13. Ge T, Wang Y, Che Y, Xiao Y, Zhang T. Atypical lateonset immune dysregulation, polyendocrinopathy, enteropathy, X-Linked syndrome with intractable diarrhea: A case report. Front Pediatr 2017; 5: 267.

14. Hwang JL, Park SY, Ye $\mathrm{H}$, et al; T2D-Genes Consortium. FOXP3 mutations causing early-onset insulin-requiring diabetes but without other features of immune dysregulation, polyendocrinopathy, enteropathy, X-linked syndrome. Pediatr Diabetes 2018; 19: 388-392.

15. Park E, Chang HJ, Shin JI, et al. Familial IPEX syndrome: Different glomerulopathy in two siblings. Pediatr Int 2015; 57: e59-e61.

16. Bacchetta R, Barzaghi F, Roncarolo MG. From IPEX syndrome to FOXP3 mutation: A lesson on immune dysregulation. Ann N Y Acad Sci 2018; 1417: 5-22.

17. Gambineri E, Perroni L, Passerini L, et al. Clinical and molecular profile of a new series of patients with immune dysregulation, polyendocrinopathy, enteropathy, X-linked syndrome: Inconsistent correlation between forkhead box protein 3 expression and disease severity. J Allergy Clin Immunol 2008. 122: 1105-1112.e1.

18. Barzaghi F, Amaya Hernandez LC, Neven B, et al Primary Immune Deficiency Treatment Consortium (PIDTC) and the Inborn Errors Working Party (IEWP) of the European Society for Blood and Marrow Transplantation (EBMT). Long-term follow-up of IPEX syndrome patients after different therapeutic strategies: An international multicenter retrospective study. J Allergy Clin Immunol 2018; 141: 1036-1049. e5. 